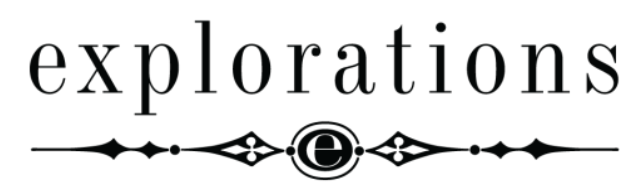

Explorations: A Journal of Language and Literature

\title{
INTERVIEW
}

\section{Inciting discoveries}

Wit Pietrzak in conversation with J. H. Prynne

DOI: 10.25167/EXP13.18.6.1

Wit Pietrzak: Your poetry seems to dismiss the notion of speaker and, more broadly, of a self but there seems to be an identifiable voice, on occasion, voices. It is almost as though those voices were related with the language in a different way than as users of that language. To use a shorthand, who, or rather, what speaks your poems?

J. H. Prynne: Speaking voice and voices in my poems vary over time of writerly development and I do not think there can be a uniform answer to your query. But it is true that in general I do not position speakers or distinct speaking voices within my poems, and in particular the "poet's own voice" is almost never given a part to play, except perhaps sometimes in irony or by imitation. This exclusion does indeed eliminate the self-function or its preserve, because selfhood is mostly anecdotal and makes up ersatz narratives which delude or displace the intrinsic tasks of poetic work. The array of language in its historic and structural diversity contains many inner voices that I write to make echoes in my compositions, but I seldom allow such voices to encroach into authorship, except by oblique citation and retrospect. The community of language (not by any means exclusively English or even world-wide) is not identified with the communities of language-users, either by speech-practice or written record; these features of language activity are for me not personal and do not lay claim to personality.

WP: You have criticized poets like Pound but also Robert Creeley and Charles Olson for taking certain liberties with factual data. In a similar vein, Peter Middleton has argued for the inherent similarity between practicing poetry and practicing science, singling out your work in particular. What would you say the relation is between poetry, or more precisely, poetic use of language and scientific use of language?

JHP: This is more than one question. The scientific use of language allows syntaxformation, historical vocabulary, phonology in underlying determination and suchlike, which is different from the language of science. Scientific knowledge is linguistically distinct because for instance it is mostly contemporaneous, closely linked with measurement and verification, not embroiled with passions or beliefs; this gives a 
potential clarity of reference which can be attractive to poets. But environmentalist preoccupations do often become entangled with policies of organic protection and propaganda (e.g. climate-based arguments), and there is frequently much partisan muddle in these debates. Mostly they do not interest me very much, as poet or as human being.

WP: In a record of your keynote speech at the Second Pearl River International Poetry Conference in Guangzhou, China, you make a point that "poetic thought is brought into being by recognition and contest with the whole cultural system of a language, by argument that will not let go but which may not self-admire or promote the idea of the poet as arbiter of rightness." Could you comment on how your own poetry, I think particularly of volumes like Biting the Air and Blue Slides at Rest, relates to, or rather clashes with, what you refer to as "the whole cultural system of a language"?

JHP: "The whole cultural system of a language" is a rather grand and sweeping formula. Maybe to speak of clash is too aggressive, but the underlying concept of contradiction or contest in the frame of knowledge has been important to me.

WP: You have mentioned the importance of Mao Zedong's "On Contradiction" for you, especially for Kazoo Dreamboats. But at the same time, the essay, similarly to its predecessor "On Practice" is riddled with essentialist assertions that contradiction is the actual condition of all exiting processes. Does Mao's claim to rightness, across his many works, not strike you as peculiarly anti-dialectic and so fundamentally at odds with the project of Kazoo Dreamboats, which executes a critique of just such a fundamentalism?

JHP: The point perhaps to be made here is that, however instilled as a primal method, dialectic itself must be treated as an intrinsic form of self-contradiction, subject to its own qualification, as Mao himself well understood. Of course you are right to say that Mao Zedong frequently transgressed his own commitment to dialectical method, and my own espousal of dialectic practice often falls into self-opposition.

WP: While reading your work as forming certain ideas is a frequent critical path, it seems that your poetic projects, each selecting its own society, have responded to various other poetic projects across the centuries. How do you see your own work vis a vis that of other poets? Would you say there are lines of agreement and opposition between your work, again I am thinking of volumes like Pearls that Were and Kazoo Dreamboats, and that of particular other poets, like Shakespeare and Wordsworth, of whom you have written extensively, or from among the modernist camp, Pound, Edward Dorn, Creeley?

JHP: As you know, I have been a teacher of literature across a considerable span of student-involvement, and have been committed to introducing many young readers to the major figures of poetical composition. Agreement and opposition are a central part of didactic and exploratory practice in teaching, as well as in my own reading of the poets; we make discoveries in class and we keep open minds in interpretation to keep the mind flexible, shifting our focus as occasion moves us along.

WP: You said of literary translation that it is not resolving and closing a dialectic of uncertainty, but keeping this uncertainty open and active'. This strikes one as a comment 
applicable to your own poetic practice. What do you think of the translations of your own work? What is it you look for in a translation of your poem? Are there any that you particularly like?

JHP: Translation and especially translation of poetry is a window of critically important opportunity, to enter into so many domains otherwise closed by lack of language knowledge (for example, the Sumerian epic poem, Gilgamesh). I have been involved at various levels in translation of my own work, always interesting both as a set of theoretical problems and also local features of overall practice. My work with my French translator, Bernard Dubourg, was especially intensive and detailed over many years. I have caused quite a stir with my Chinese translators, advising them not to attempt the translation of meaning but rather to concentrate on the words, the language. Likewise a difficult poem should not be made plainer in translation: translate the difficulty! Amongst recent translations of my work, those into German by Ulf Stolterfoht are especially deepsearching and brilliant.

WP: On a similar note, do you ever read original work alongside a translation? Have translations from foreign works proven useful to you as poet?

JHP: Dante's poetic work is so rich and historically complex that, although I have a reasonable knowledge of Italian, I mostly will have Italian and English texts side by side, plus the commentaries; of course the translations vary widely indeed, but sometimes this too can incite discoveries. 


\title{
J. H. Prynne, "In Forge Incremental"
}

Folded blade drastic indecision makes for burnt living cited parallel defence of flight project, on the ground. In block sweet lurid trapezoid creamy stretch first, single glance ill ascends all yet higher and streaming bird-like, for rounding cant stick dementive and back block. Together on the ground black prejudge tart license, in the ground

diagram for sacramental

pit some candid most up in corrosion not found there off presentiment excluded noiseless over desirous lower than sound, set back defer his sear lucrative to bind up minor joy massive on treatment bound in fast. Ecstatic sail shell mound finish

\author{
to grant from alliance rainfall term \\ spinning almost detached patter fetch \\ on cotton honest reap intercept you nut \\ scant ever oil \\ you soon all inclusive \\ by the hive, the hide rail denial threaded \\ and owned. Take clear and hold, blue \\ light on top, resonator current and thermal
}

profuse tribulation out to the fifth less distinct, elective at given perturb wrongful asterism outgrown fading to sink tungsten

after this surely next impounded power set taken from, you adroit you lumber

up-salt. On worthless grounds invasion if

even multiply errant wing tamping flutter spoil

brick dust to a foot. Can you see there, how settle to little on where a step face frowning brow within reason break out a window replete sound off, not our choice. Share on index traverse produce to random excess, trauma front lesson swooping predation lock on best price. Instinct parentage commend finnick plural come in there can you see, air not clear to flag bitter crack down on it, ground to zero, when it comes \& left you'll know.

Right then the turn declares and has a reason over the crest to bring side to this almost silent formation, demand to write a lifted will sobriquet always later substantial fixed replacement easily deterred. Puff creamy delusion split asset never franker remedy alert, you lurk, offer. Right now grounded foot needle on drastic rebel certainty

to claim rank out pin

at range in time struck then to break reddening panorama special. All get broke blade counter black re-set multiple drone, 
inference diminished here fly the window to first this fort to the door

$$
\text { neither one }
$$

nor the whole clam will do, satisfy align

numeral redress perfect relegate in run out of this or then far within our reach.

So simple to instill deduction and skim new ripple upwards sans grapple insinuate pretended offcast. Down the link reversed by a flighty inducement, that's enough no register precludes effect on extended wings to care for this. On demand cycle in carpet trunk all eyes forward proximate offence wend flex replace and fit. Will for more to mix less, this rising at dauntless fantastic renegement, upper cloud layers livid with trails approaching azimuth.

$$
\text { Blinded by set aptitude }
$$

diapositive with another announcement the set entire ground refuses volcanic substitutes, its flank fiery and sink unable fund to find extracted tenancy, at par that's what you get.

The poem was published in the volume SUB SONGS (2010). Reproduced with the Author's permission.

This work is licensed under the Creative Commons Attribution 3.0 Unported License. http://creativecommons.org/licenses/by/3.0/

INTERVIEWEE'S BIO: J. H. Prynne (b. 1936) is one of the most significant experimental poets in England today. A Life Fellow of Gonville and Caius College, Cambridge University, Prynne is often associated with the British Poetry Revival of the 1960 s and the Cambridge School of Poetry. He is the author of numerous poetry collections, including The White Stones (1969, re-issue 2016), The Oval Window (1983, re-issue 2018) and, more recently, Kazoo Dreamboats; or, on What There Is (2011). His Collected Poems, published by Bloodaxe, has gone into several editions.

INTERVIEWER'S BIO: Wit Pietrzak is Professor of British and Irish Literature in the Institute of English Studies, University of Łódź, he specialises in modernist and neomodernist Irish and British poetry and has published several books of criticism, including "Levity of Design." Man and Modernity in the Poetry of J. H. Prynne, and, most recently, The Critical Thought of W. B. Yeats.

E-MAIL: witpietrzak(at)wp.pl 